\title{
Improving properties of Viscose fabric by water repellent finish
}

\author{
Trinh Thi Kim Hue ${ }^{*}$, Bui Mai Huong
}

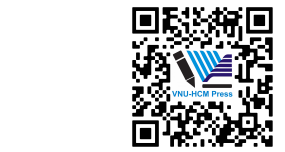

Use your smartphone to scan this QR code and download this article

Department of Textile Garment Engineering, Faculty of Mechanical Engineering, Ho Chi Minh City University of Technology, VNU-HCM, Vietnam

Correspondence

Trinh Thi Kim Hue, Department of Textile Garment Engineering, Faculty of Mechanical Engineering, Ho Chi Minh City University of Technology, VNU-HCM, Vietnam

Email: ttkhue@hcmut.edu.vn

History

- Received: 02-11-2020

- Accepted: 27-02-2021

- Published: 15-03-2021

DOI : 10.32508/stdjet.v4i1.788

\section{Check for updates}

Copyright

(c) VNU-HCM Press. This is an openaccess article distributed under the terms of the Creative Commons Attribution 4.0 International license.

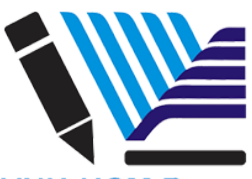

VNU-HCM Press

ABSTRACT

Viscose is the most abundantly available man-made cellulose fibers. Viscose has several good functional properties such as high water absorption, easier dye ability, comfort feel when wearing. Most of the apparel products are made of cellulose based fabrics. However, the disadvantages of viscose fabrics include the low dimensional stability, easy wrinkle. To enhance the functional properties of viscose fabrics, many finishing processes have been applied such as water repellent finishing. One of the acrylate polymers was used to finish textiles is fluorocarbons. They applied to the cellulose fabric surface can significantly improve contact angle between water drops and fabric surface as well as other properties. In this paper, Nuva1811, Ruco Dry ECO, FW-500D were evaluated the impact on viscose fabric. The efficiency of the process implementation was determined by measuring and analyzing the physical properties of fabric samples. Viscose fabric treated with Nuva 181160 $\mathrm{g} / \mathrm{l}$ was evalutated the high water repellency with level 4 after finishing. However, the washing fastness properties was decreased slightly. When applied in the fiber, the polymer will form a structure that presents $\mathrm{CF}_{3}$ outer surface for maximum repellency. Fluorocarbons provides fiber surfaces with the lowest surface energies of all repellent finishes. The results show that the viscose reveals the higher wet strength, indicating the possibility of FC deposited on the surface of fibers to the capillary inter fiber or inter yarn spaces in the fabric. Tensile strength of viscose fabric was increased $24.6 \%$. The shrinkage percentage of coated viscose was decreased (only $3 \%$ when was treated with Nuva 1811 compare to the untreated fabric 9.5\%). Furthermore, the abrasion resistance of viscose fabric has increased because the weight loss of fabric was decreased $(0.42 \%$ when was treated with Nuva 1811 for 1000 cycles compare to the untreated fabric 1.4\%). The morphology of the untreated and treated viscose fabrics were characterized via a scanning electron microscope.

Key words: Viscose, wet strength, water repellent, chemical finish, fabric

\section{INTRODUCTION}

Today viscose is an important cellulosic fiber mostly used in textiles. The most abundant source of cellulose is wood, of which it constitutes about $50 \%$. Regular viscose is different from cotton in having non fibrills, having no lumen, and having a much lower degree of polymerisation. Viscose staple fibers are produced in the types of linear densities ranging from 0.1 to 0.8 tex and lengths from 40 to $120 \mathrm{~mm}$ to suit the characteristics of other commonly used textile fibers such as cotton, silk ${ }^{1,2}$. The fabric made from viscose fibers will be soft, comfortable in hot and humid conditions, drape well, highly absorbent and easy to dye. However, viscose fabrics have not so high dimensional stability in washing, creasing, and tend to very strong stretch. Compared with cotton or the other cellulose such as lyocell, modal, viscose has the several disadvantages of much lower breaking strength, particularly when wet ${ }^{3}$.

The water repellent finishing has been reported in numerous works nowadays to improve textile properties. Water repellency is the ability to push water down in the form of droplets on the surface of the fabric, causing water droplets not to spread over the surface and prevent the fabric from getting wet. The water resistance of the fabric mainly involves in textile fiber properties and the density of the textile materials. The hydrophobicity of the fiber is evaluated by the difference in surface energy between fabric and liquid. It is reasonable to make difference between "waterrepellent" with "waterproof". "Water-repellent fabric" is a fabric with many holes and is capable of venting and evaporating water. This fabric allows the water to pass through it when the used pressure is high enough. "Waterproof fabric" is water resistant fabric under hydrostatic pressure much higher than "Waterrepellent fabric". This fabric has fewer holes and the air permeability and water vapor is also worse ${ }^{2,3}$. All of those finishing methods must ensure the breathability and the comfort of the fabric. FC provides the lowest surface energies in all the finishes in using it. It is still used to finish the high efficiency for water and oil repellency ${ }^{4,5}$. The fluorocarbons are synthesized by make bonding between perfluro alkyl groups or urethane monomers to form polymer which will 
be on fabric after finishing. The FC products can be greatly modified for many the other special properties of textile materials.

In this paper, we apply the FC the water repellent technology on $100 \%$ Viscose fabric ${ }^{6-8}$. The three different water repellent options used are Nuva 1811 combines acetic acid; Ruco Dry combines acetic acid and FW-500D combines acetic acid. The repellency, tensile strength, abrasion durability tests and SEM image analysis are used to characterize and compare the water repellent performance of the three methods.where is citation ${ }^{9}$ ?

\section{MATERIALS AND METHODS}

\section{Materials}

The plain woven $100 \%$ viscose fabric, , mass per unit area of fabric $2.05 \mathrm{~g} / \mathrm{m}^{2}$, count of warp 65 threads $\mathrm{cm}^{-1}$, count of weft 50 threads $\mathrm{cm}^{-1}$, were scoured and supplied by Tam Xuan Company in Viet Nam. Samples were prepared with the size of $20 \mathrm{~cm} \times 20$ $\mathrm{cm}$.

The chemicals used to include Nuva 1811 (Archroma, Switzerland); Ruco Dry ECO (Rudolf, Germany); FW-500D (R.O.C, Taiwan); acetic acid (99.9\%) were purchased from Xilong Chem Co. Ltd. (China). Three kinds of chemicals are fluorocarbon- based acrylate polymer. Nuva 1811 is C6 based fluorocarbon. Ruco Dry ECO is made from FC wax. It has proper characteristics as the cationic, water repellency is very good with monomers with the trend of sustainable developments. FW-500D is C8 based fluorocarbon.

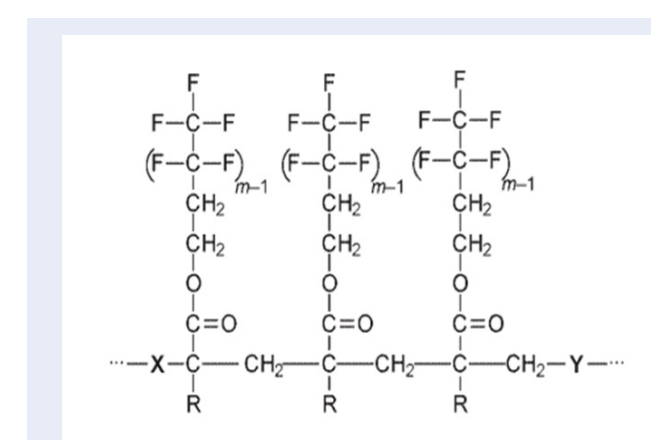

Figure 1: Chemical structure of perfluorinated acrylate.

\section{Treatment methods}

Three treatment methods were applied. The sample code was marked as Xa where X is the type of chemicals, $\mathrm{a}$ is the code of different chemical concentrations as described in Tables 1, 2 and 3.

\section{Nuva 1811 with catalyst acetic acid}

The samples were padded to $80 \%$ wet pickup approximately with prepared solutions. The padded fabrics were dried at $110^{\circ} \mathrm{C}$ for $3 \mathrm{~min}$, and cured at $150^{\circ} \mathrm{C}$ for $5 \mathrm{~min}$.

\begin{tabular}{lll} 
Table 1: The details of treatment method $\mathbf{1}$ \\
\hline Recipe name & $\begin{array}{l}\text { Chemical concentrations } \\
\text { Nuva } 1811\end{array}$ & $\begin{array}{l}\text { Acetic acid } \\
(\mathrm{ml} / \mathrm{l})\end{array}$ \\
& $(\mathrm{g} / \mathrm{l})$ & 3 \\
N40 & 40 & 3 \\
N50 & 50 & 3 \\
N60 & 60 & \\
\hline
\end{tabular}

\section{Ruco Dry ECO with catalyst acetic acid}

The samples were padded to $80 \%$ wet pickup approximately with prepared solutions. The padded fabrics were dried at $110^{\circ} \mathrm{C}$ for $3 \mathrm{~min}$, and cured at $150^{\circ} \mathrm{C}$ for $5 \mathrm{~min}$.

\begin{tabular}{|c|c|c|}
\hline \multirow[t]{2}{*}{ Recipe } & \multicolumn{2}{|c|}{ Chemical concentrations } \\
\hline & $\begin{array}{l}\text { Ruco Dry ECO } \\
(\mathrm{g} / \mathrm{l})\end{array}$ & Acetic acid (ml/l) \\
\hline $\mathrm{R} 40$ & 40 & 3 \\
\hline R50 & 50 & 3 \\
\hline R60 & 60 & 3 \\
\hline
\end{tabular}

\section{FW-500D with catalyst acetic acid}

The samples were padded to $80 \%$ wet pickup approximately with prepared solutions. The padded fabrics were dried at $110^{\circ} \mathrm{C}$ for $3 \mathrm{~min}$, and cured at $150^{\circ} \mathrm{C}$ for $5 \mathrm{~min}$.

\section{Table 3: The details of treatment method 3}

\begin{tabular}{llll}
\hline Recipe name & \multicolumn{2}{l}{ Chemical concentrations } \\
& FW-500D $(\mathrm{g} / \mathrm{l})$ & $\begin{array}{l}\text { Acetic } \\
(\mathrm{ml} / \mathrm{l})\end{array}$ & acid \\
F40 & 40 & 3 \\
F50 & 50 & 3 \\
F60 & 60 & 3 \\
\hline
\end{tabular}

\section{Water repellent rating measurement}

Rating test was used AATCC-22 (Spray test). The water repellent rating was performed according to the 
level from 0 to 5 .

Tensile strength and abrasion resistance measurements

The tensile strength of the fabric was tested with ISO 13934-1:1999. Abrasion resistance test was determined with ISO 12947-3. The tests were conducted at different cycles to check the weight loss of fabrics.

\section{Dimensional stability}

Dimensional stability test was determined with AATCC-135.

\section{Characterization}

The morphology of the fabric samples were characterized via using scanning electron microscopy (SEM, Zeiss Evo10).

\section{Washing Test}

The Washing procedure was performed following standard test method AATCC - 135 . The setting temperature for washing test was approximately $40^{\circ} \mathrm{C}$.

\section{RESULTS AND DISCUSSION}

\section{Repellent results}

The untreated viscose fabrics exhibited no water repellent. The drops of water will spread on the surface of fabric. The contact angle between the contact angle between the water drop and the fabric surface is smaller than $30^{\circ}$. Nuva1811 has revealed clearly an excellent improvement in making drops of water stay on the surface and drip off easily. The obtained testing value was level 4 at $60 \mathrm{~g} / \mathrm{l}$ of the Nuva 1811 finish. The results were given in Table 4, Figure 2.

Table 4: Repellency results (the best rating in each method) after finishing treatment on fabric

\begin{tabular}{ll}
\hline Method & Repellency rating Water \\
No treatment & 0 \\
N60 & 4 \\
R60 & 3.5 \\
F60 & 3 \\
\hline
\end{tabular}

*'0 0 ' is zero; fabric sample is absolutely wet.

The water on treated fabric will not spread on the surface of fabric. The drops of water were not much contacted with fabric surface.

In method 1,2,3 when dripping the water drops on the fabric surface, the contact angle between the water drop and the fabric surface is much increased. It is

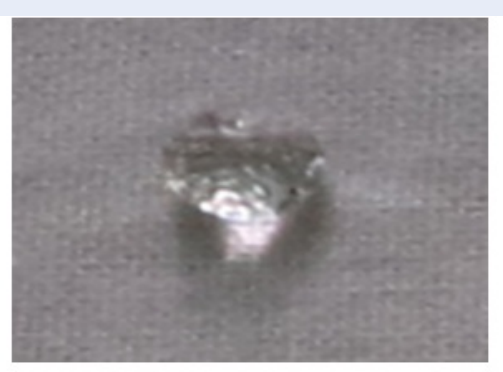

(a)

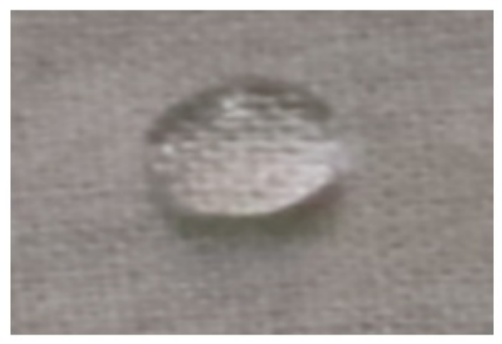

(b)

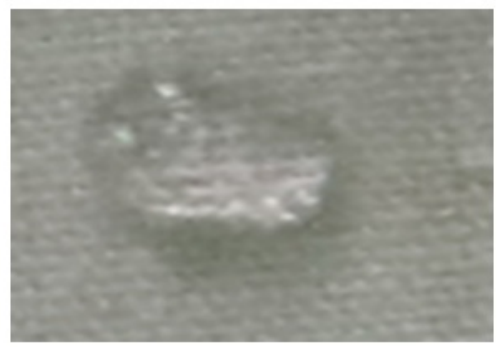

(c)

Figure 2: Water repellent capacity of Viscose fabric treated with $\mathrm{N} 60$ (a), R60(b), F60(c) after 24h.

clearly observed from Figure 2 that It is greater than $90^{\circ}$. This results show that the formation of FC layer on viscose fiber which was responsible not to be wet or repel water.

The repellent washing fastness of the finishing viscose fabric was greatly maximum to 10 washing. Nuva 1811 is fluorocarbon polymer which is synthesized from acrylate monomers and can form sufficient functional groups for binding and adhering on the surface of fibers or inter fibers in the viscose fabric. So mechanism can be that cross-linking of the cellulose and the Nuva 1811 (C-O-C) creates the linkage in treating process is better and the washing fastness of samples were good. The results were given in Table 5 . 
Table 5: Effect of 10 washing cycles on the durability of finish

\begin{tabular}{ll}
\hline Method & $\begin{array}{l}\text { Repellency rating Wa- } \\
\text { ter }\end{array}$ \\
No treatment & 0 \\
N60 & 4 \\
R60 & 3 \\
F60 & 2 \\
\hline
\end{tabular}

*' 0 ' is zero; fabric sample is absolutely wet

The washing test after finishing exhibited that the treated fabric remained the repellent ability at level 2-4 and the droplet retaining time ensured at $4 \mathrm{~h}$. The different methods strongly influenced on washing fastness of treated fabrics.

Regarding the tensile strength of fabric, it can be seen that the strength of all finished fabric increased compared to untreated fabric. The untreated viscose has poor wet strength (70.4 for warp and 112.8 for weft). Viscose has a higher water absorbency than cotton or the other cellulose. When penetrating water, the fabric will uptake more water and begin to much swell. It is reasonable to make fiber to decrease breaking strength on it. After finishing process, the surface energy of the treated fiber will decrease obviously. Therefore it can lead to absorb lower water and enhance the wet resistance. Finally, recipe viscose treated with Nuva $181160 \mathrm{~g} / \mathrm{l}$ has showed the highest wet strength (140.6 lbf for weft). The results were shown in Figure 3.

As the results were presented in Figure 4, fabric before finishing has the low wet elongation $(29.2 \%$ for warp and $31.2 \%$ for weft). After the water repellent finishing, elongation was improved $(44.6 \%$ for warp and $34.2 \%$ for weft). Recipe viscose treated with Nuva $181160 \mathrm{~g} / \mathrm{l}$ has showed the highest elongation.

To durability, original viscose obtained $0.9 \%$ weight loss in 500 cycles and $1.4 \%$ weight in 1000 cycles. After padding finishing, the weight loss of viscose was decreased $(0.3 \%$ and $0.42 \%$ at N60 for 500 cycles and 1000 cycles). The results were presented in Table 6.

As given in Table 6, we have found that fabric's abrasion resistance has increased gradually after finishing with the water repellent agents.

The coated viscose has shrinkage percentage (at N60$3 \%)$ compare to the untreated fabric (9.5\%). The treated viscose fabric improved the shrink resistant of fabric after washing. The results were shown in Figure 5.

SEM analysis images of samples as presented in Figure 6 with 500x manification. SEM images confirmed
Table 6: Weight loss of viscose for different cycles

\begin{tabular}{lll}
\hline Recipe name & Weight loss (\%) \\
& 500 cycles & 1000 cycles \\
No treatment & 0.9 & 1.4 \\
N40 & 0.42 & 0.73 \\
N50 & 0.49 & 0.56 \\
N60 & 0.3 & 0.42 \\
R40 & 0.38 & 0.67 \\
R50 & 0.23 & 0.49 \\
R60 & 0.39 & 0.46 \\
F40 & 0.42 & 0.6 \\
F50 & 0.39 & 0.7 \\
F60 & 0.27 & 0.47 \\
\hline
\end{tabular}

that the existence of Nuva 1811 layer adhered onto the viscose fibers after treating processes. There were no samples with deformation in the fabric structure or damages on fibre surface. It can be confirmed that the chemical used in these treatment are safe and feasible for fabric. Surface of fabric is rough in case of using FW-500D. The reason can be that the presence of chemical coated on fabric surface is not uniform.

\section{CONCLUSION}

All testing results in this study confirmed that the water repellent finished fabric exhibited the good properties. The samples N60 of method 1 showed a mild water repellent ability with a concentration of $60 \mathrm{~g} / \mathrm{l}$. The samples finished with method 2 and 3 proved the good repellent as they finished with FC chain C6 and C8. In general, the water repellent capacity of the finished fabric is reduced, but not worth much after 10 washing cycles. The aim in the study is to improve the disadvantages of viscose fabric including its wet resistance and these physical properties were greatly changed by using of water repellent finishes. Elongation at the wet condition was improved. Similarly, fabric tensile strength was also increased after finishing with FC chemicals. Viscose fabric shrinks higher than the other cellulose fabrics. Abrasion resistance and dimensional stability of viscose were also considerably increased after utilizing the potential finishing agent in textile industry. The results also showed that the sample with the best water repellent was N60 in method 1 . Therefore viscose has a very good sustainable development trend to replace the other cellulose fabrics after using different FC polymers to finish water repellent. 


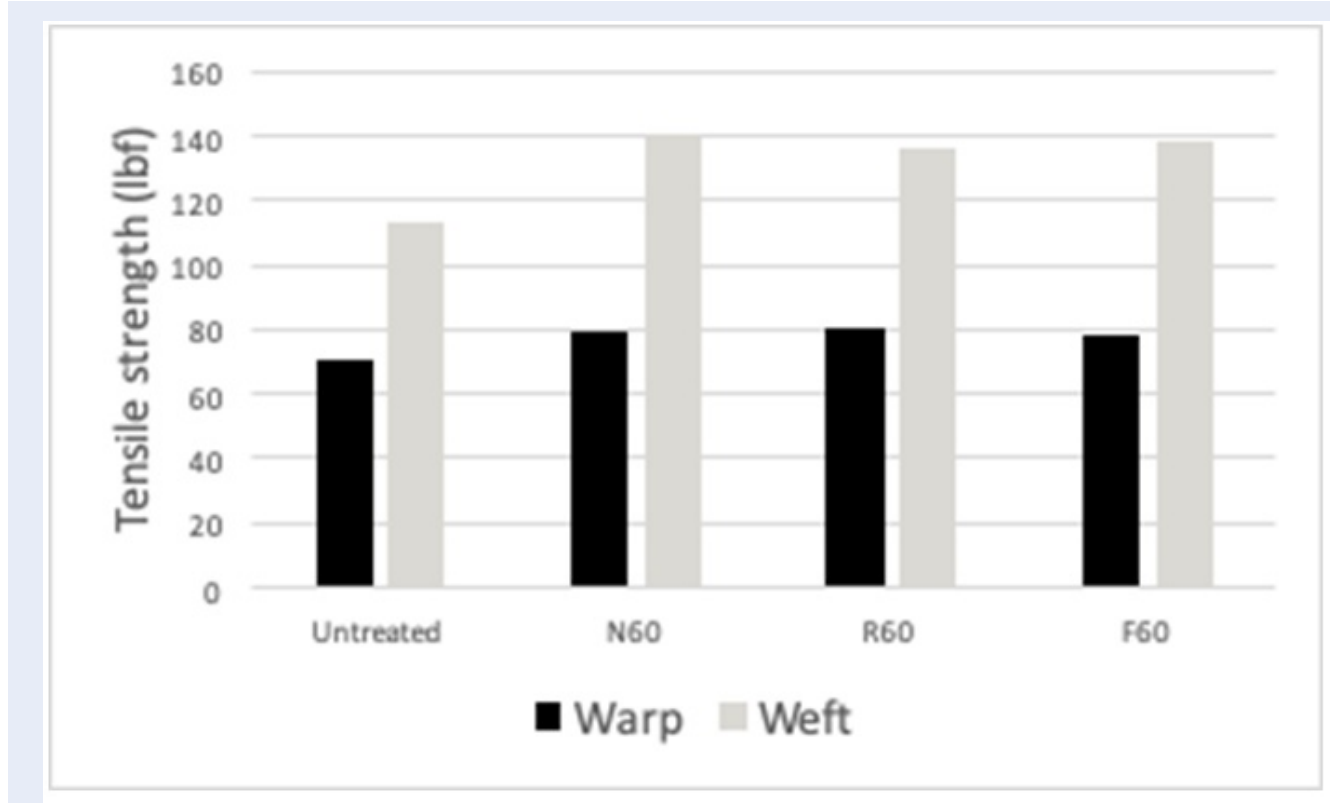

Figure 3: Changes in tensile strengh of treated viscose fabric compared to untreated fabric (wet condition)

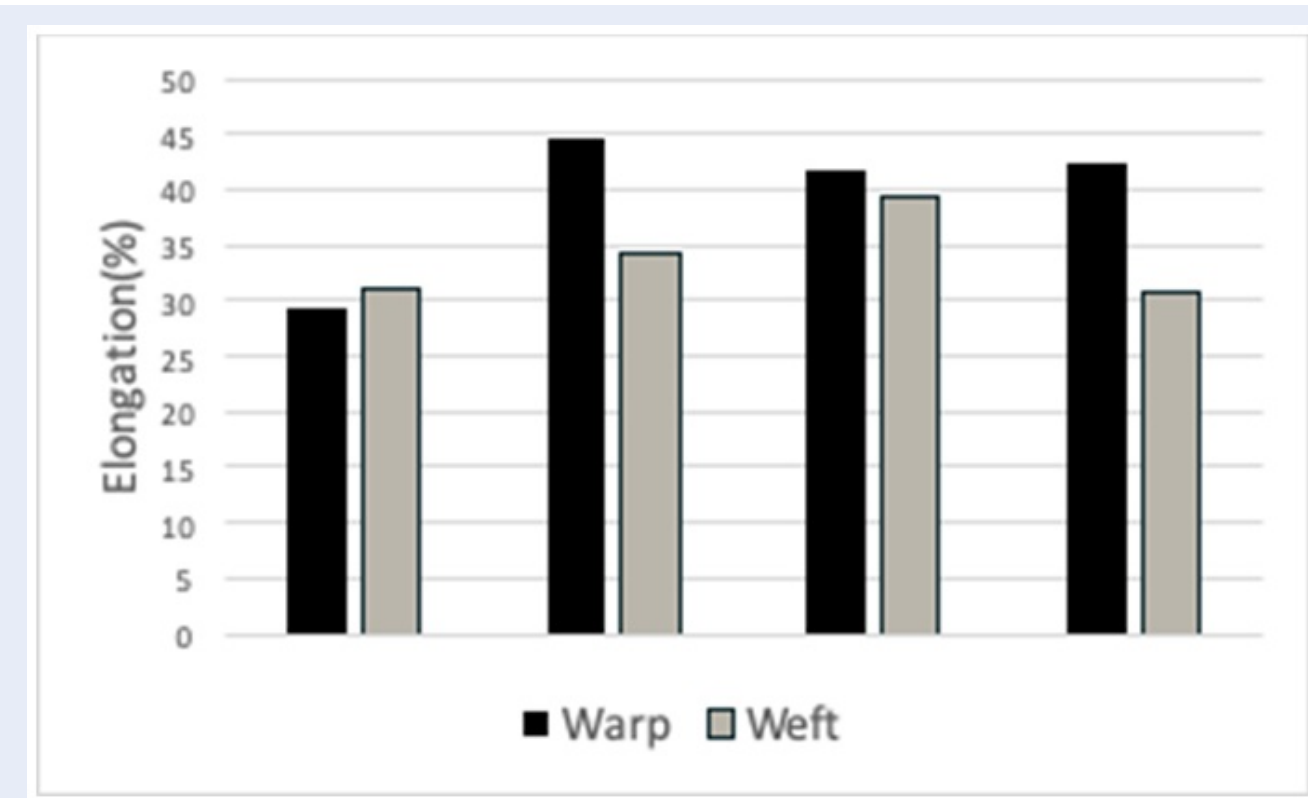

Figure 4: Changes in elongation $\%$ of treated viscose fabric compared to untreated fabric (wet condition) 


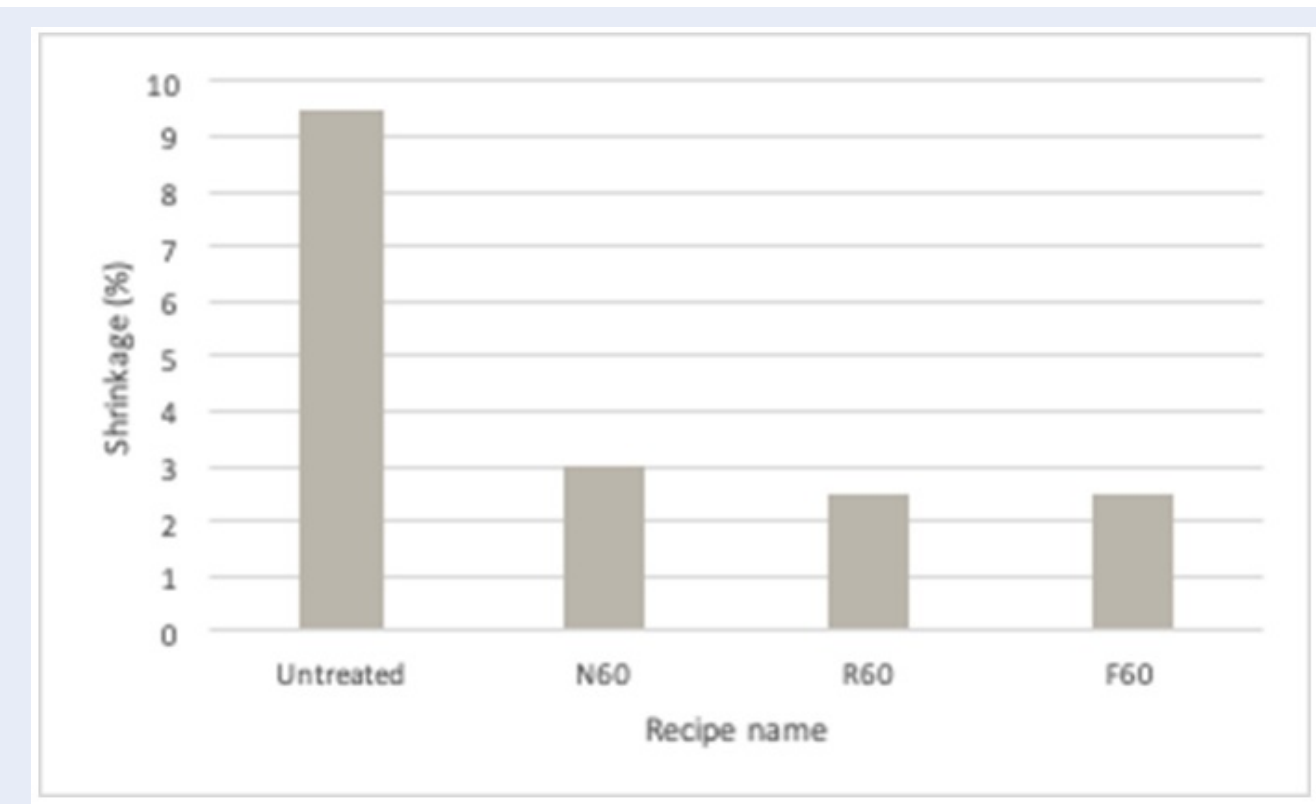

Figure 5: Changes in shrinkage \% of treated viscose fabric compared to untreated fabric (wet condition)

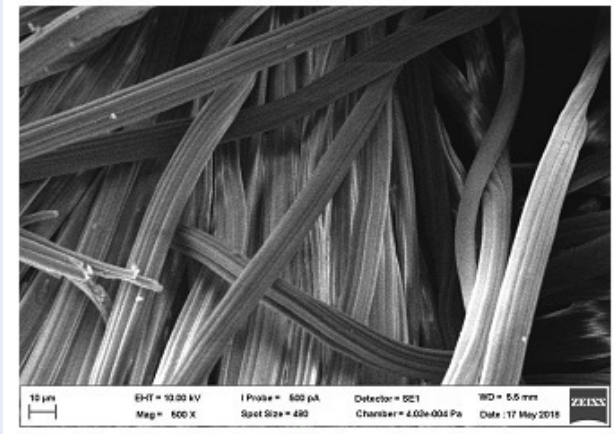

(a)

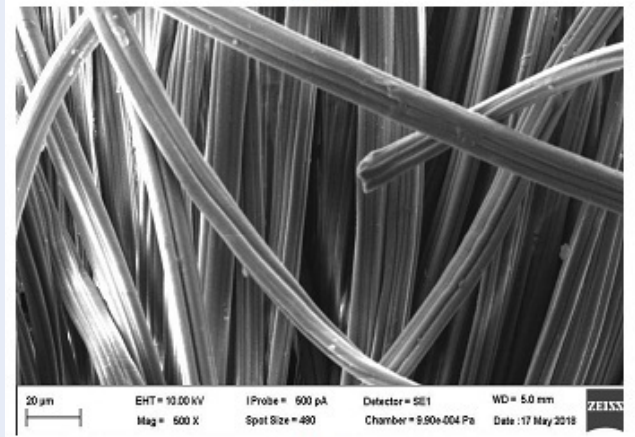

(b)

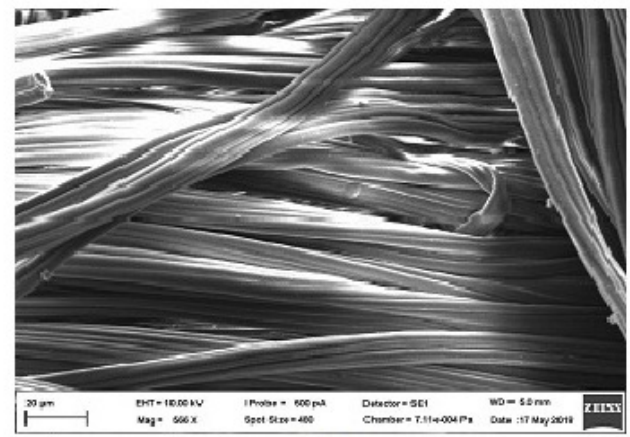

(c)

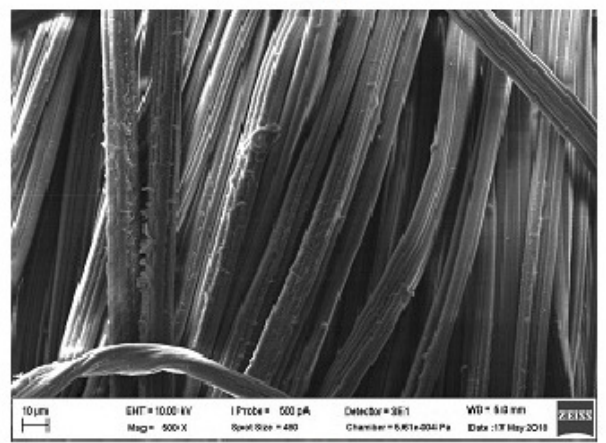

(d)

Figure 6: SEM image of untreated viscose (a)and treated viscose fabric N60,R60,F60 (b,c,d) 


\section{ACKNOWLEDGMENT}

This research is funded by Ho Chi Minh City University of Technology-VNU-HCM under grant number T-CK-2019-22.

\section{ABBREVIATIONS}

FC: Fluorocarbon

SEM: Scanning Electron Microscope

\section{CONFLICT OF INTERESTS}

The author declares that there is no conflict of interests regarding the publication of this paper.

\section{AUTHORS' CONTRIBUTION}

Trinh Thi Kim Hue is in charge of all research content presented in the article.

Bui Mai Huong check and review the article.

\section{REFERENCES}

1. Heywood D. Textile finishing, Chapter 1,2, Bradford, Eng.: Society of Dyers and Colourist. 2003;.

2. Williams JT. Waterproof and Water Repellent Textiles and Clothing. Woodhead Publishing. 2018;

3. Sato Y, et al. Effect of Crosslinking Agents on Water Repellency of Cotton Fabrics Treated with Fluorocarbon Resin. Textile Research Journal . 1994;64(6):316-320. Available from: https: //doi.org/10.1177/004051759406400602.

4. Castelvetro V, Francini G, Ciardelli G, Ceccato M. Evaluating Fluorinated Acrylic Latices as Textile Water and Oil Repellent Finishes. Textile Research Journal. 2001;7(5):399-406. Available from: https://doi.org/10.1177/004051750107100506.

5. Morton WE, Hearle JWS. Physical properties of textile fibres - Fourth edition. Woodhead Publishing. 2008;Available from: https://doi.org/10.1201/9781439831830.

6. Schindler WD, Hauser PJ. Chemical Finishing of textiles. Woodhead Publishing. 2004;Available from: https://doi.org/10.1201/ 9781439823477.

7. Paul R. Functional Finishes for Textiles: Improving Comfort, Performance and Protection. Woodhead Publishing. 2014;

8. Rowen JW, Gagliardi D. Properties of Water-Repellent Fabrics. 1947;38. Available from: https://doi.org/10.6028/jres.038.002.

9. Choudhury AKR. Principles of Textile Finishing, Woodhead Publishing. 2017;. 


\title{
Nghiên cứu cải thiện tính chất của vải viscose bằng phương pháp hoàn tất chống thấm
}

\author{
Trịnh Thị Kim Huệ*, Bùi Mai Hương
}

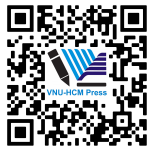

Use your smartphone to scan this QR code and download this article

\section{TÓM TẮT}

Viscose có nguồn gốc từ cellulose, loại vải rẻ nhất trong các loại vải gốc cellulose có thể là lựa chọn thay thế tốt nhất hiện nay. Viscose được sản xuất từ cellulose tái sinh. Viscose là một sản phẩm dệt thân thiện với môi trường. Do đó, nhu cầu về các sản phẩm dệt thân thiện với môi trường tăng sẽ làm tắng nhu cầu về sợi visco và giảm bớt sản lượng cotton như hiện nay. Vải viscose thể hiện một số tính chất tương tự như vải cotton ngoại trừ độ bền ướt kém do độ hồi ẩm cao hơn. Trong nghiên cứu này, hoàn tất hoá học bằng các chất liên kết ngang khác nhau đã được áp dụng để cải thiện độ bến ướt của vải viscose. Các polymer acrylate gốc fluorocarbon như Nuva 1811, Ruco Dry ECO, FW-500D được đánh giá trên vải viscose. Vải được xử lý với Nuva 181160 g/l có kết quả chống thấm nước tốt trước khi giặt. Kết quả chống thấm trên vải đạt mức 4 sau khi xử lý. Tuy nhiên, mức chống thấm giảm sau khi giặt. Các chuỗi fluorocarbon của polyacrylate được định hướng ra ngoài bể mặt xơ và các nhóm $-\mathrm{CF}_{2} \mathrm{CF}_{3}$ hình thành một lớp chống thấm năng lượng thấp. Hoàn tất chống thấm nước giúp làm giảm lực cản giữa các phân tử xơ riêng lẻ và làm giảm sức căng bề mặt của vải. Nó làm giảm khả năng thấm hút của vải viscose dẫn đến làm tăng độ bền ướt. Vi vậy, vải viscose đã qua xử lý thể hiện độ bền ướt tốt hơn sau khi đã hoàn tất chống thấm lên nó. Độ̣ bền kéo của vải viscose tăng lên $24.6 \%$. Độ co của vải viscose chỉ còn $3 \%$ sau khi xử lý với Nuva 1811 so với vải chưa xử lý có độ co là 9,5\%. Độ mài mòn cũng đã giảm chỉ còn $0,42 \%$ cho trường hợp 1000 vòng sau khi xử lý với Nuva 1811 so với vải chưa xử lý là 1,4\%. Kính hiển vi điện tử quét (SEM) được sử dụng để kiểm tra bề mặt của vải sau khi xử lý bằng hoá chất.

Từ khoá: Viscose, độ bên ướt, chống thấm nước, hoàn tất hoá học, vải
Bô môn Kỹ thuât Dệt may, Khoa Cơ khí, Truờng Đại học Bách khoa TP HCM, ĐHQG-HCM, Viẹt Nam

\section{Liên hệ}

Trịnh Thị Kim Huệ, Bộ môn Kỹ thuật Dệt may, Khoa Cơ khí, Trường Đại học Bách khoa TP HCM, ĐHQG-HCM, Việt Nam

Email: ttkhue@hcmut.edu.vn

Lịch sử

- Ngày nhận: 02-11-2020

- Ngày chấp nhận: 27-02-2021

- Ngày đăng: 15-03-2021

DOI : 10.32508/stdjet.v4i1.788

\section{Check for updates}

\section{Bản quyền}

๑ Đ ĐHQG Tp.HCM. Đây là bài báo công bố mở được phát hành theo các điều khoản của the Creative Commons Attribution 4.0 International license.

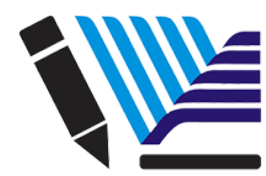

VNU-HCM Press
Trích dẫn bài báo này: Huệ $T \mathrm{~T} K$, Hương $\mathrm{B} M$. Nghiên cứu cải thiện tính chất của vải viscose bằng phương pháp hoàn tất chống thấm. Sci. Tech. Dev. J. - Eng. Tech.;4(1):697-704. 